\title{
力覚呈示機能をもつ車いす仮想体験システムの試作と空間認知実験*
}

\author{
藤 本 英 雄 ${ }^{* 1}$, 陳 連 怡*1 \\ 佐 野 明 人*1, 櫻 井陽 - *2
}

\section{Development of Wheelchair Experience System with Force Feedback and Experiments of Spatial Recognition in Virtual Environment}

\author{
Hideo FUJIMOTO, Lian-Yi CHEN, \\ Akihito SANO and Yoichi SAKURAI
}

\begin{abstract}
As an application of virtual reality to welfare work, an obstacle experience system was proposed in which a healthy person can experience the situation with a wheelchair. It is considered that such wheelchair experience system is necessary in dealing with the wheelchair's problems such as the development of new wheelchair and other welfare implements, and the design of cities and various facilities. In this research, a wheelchair experience system, which is capable of moving in a virtual environment with vision information and force feedback, was constructed. This paper describes mainly the development of force feedback system and a fundamental experiment about the movement characteristics with spatial recognition. Experiments of distance assessing by movement are done in the real and virtual environment with the attention to concept of sensory integration and active to evaluate the necessary of force feedback. The results of the experiment are discussed and the effectiveness of present system are inspected.
\end{abstract}

Key Words: Mechatronics and Robotics, Human Interface, Virtual Reality, Wheelchair Experience, Force Feedback, Spatial Recognition

\section{1. 緒言}

近年, 福祉・医療に関して社会的な関心が高まり， それに伴い福祉・医療分野への工学的研究がなされて いる(1)。また，人工現実感（バーチャルリアリティ） が，新しいヒューマンインタフェース技術として注目 され，さまざまな分野で応用研究が行われている．工 学分野での人工現実感の最大の魅力は, 人を中心に扱 うその概念である。この意味から人を対象とする福祉 工学への人工現実感の応用への期待が大きい. 福祉分 野では，リハビリテーション訓練のため，人工現実感 のアミューズメント性やシミュレーション技術が用い られている(2).

本研究では，人工現実感を利用した障害体験システ ムとして，車いす体験システムの開発を目的としてい る。車いすは，福祉機器としてよく利用されているが， その性能の限界や，都市環境の不整備によって，実際 多くの問題が生じている。しかも，一般の人々の，こ れらの問題に対する認識は，極めて低く，対策も十分

* 原稿受付 1997 年 7 月 30 日

*1 正員, 名古屋工業大学工学部（需 466-8555 名古屋市昭和区 御器所町).

*2 日本電信電話 (株) (业 100-0011 東京都千代田区内幸町 1-1 7).
ではないそここで，車いす体験システムによって，車 いすによる移動状況を仮想的に体験することにより， 障害者に対する理解，車いすの問題の認識や，新たな 車いすの開発，また車いすの移動特性を考慮した施設 や都市の設計ができるのではと考えている。

数年前から，日本の労働省や米国のオ八イオ州立大 学で電動車いす操縦訓練用のシミュレータが開発され ている，また最近，商用ベースの高齢者向け電動車い すシミュレータが開発され，福祉施設や病院などへの 導入の動きが活発化してきている。一方，より多くの 利用者がある手動車いすの体験システムの研究・開発 例はまだ非常に少ないのが現状である。しかし，安易 性，安全性抢よびリハビリ効果の面から，手動車いす の利用がこれからも広がっていくことが予想され，手 動車いす体験システムの開発が急務とされている.

上述の理由から，本研究では手動車いすを対象とし ている。これまで開発してきたシステムでは，視覚呈

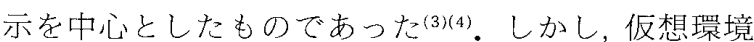
に扔いて，臨場感を高めるためには，できるだけ複数 の感覚情報と運動系を整合させることが望まし ( $^{(5)(6)}$. 近年, 視覚に伴う触覚や力覚呈示の必要性が 認識されつつある(7)．特に障害体験を考えたとき，例 えば，実際の道路には必ず存在する坂道等での乗り具 
合を体験する場合，よりリアルに困難さ等示するた めには，運動による才覚情報や環境からのフィードバ ックなどの力覚呈示が必要となる。

そこで, 本諭文では, 感覚統合と能動性 $\left({ }^{(8)} の\right)$ 锶点か ら，移動中の視覚情報とともに車いすを漕いだときの 力覚情報に着目し，打覚挂示システムを開発，新たに 力覚情報や環境からのフィードバックなどの星示機能 を車いす体験システムに取人れる。さらに，于動本い すの移動による空間認知の問題は，ある意味で視覚と 触運動（力覚を伴った車いすを漕ぐ動作）の統命の問 題と見ることができることから，車いすの移動による 空間認知を，新たに試作した衰いす体験システムの評 価基準として採用する。

2 章では，空間諗知に対して感賞統合の钼点から， 標準スケールに抢ける能動性の影響について調べる。 3 章では, 試作した力覚呈示機能を付加したシステム の構成を述べる。4章では，平坦路と坂道索考虑した 車いすの運動方程式，およびす筧呈示・制御のう式に ついて説明する。 5 章では, 試作したシステムを肺い て，車いす体験における力覚星示の有意性について実 験的な検証を行う。また，試作したシステムは垁空間 を反映することができるかどうか，システムの妥当性 を確かめる。

\section{2. 車いすの移動における 能動性の影響}

$2 \cdot 1$ 力覚呈示と能動性これまでの人厂現実感 抒よび福祉の研究では, 組立作業やコンピュータの画 像によるリハビリテーションのような手の㕍く範世比 対象とした視知覚空間と呼ばれる狭い範[过（スモール スケール(9)のものが多い. それに対し，車いす体験 システムでは，比較的大きな空間（標準スケール）を 対象にしている。

従来の研究により，スモールスケールでの感覚統合 には，能動性が影響することがわかっている(10). 一 方，標準スケールでも能動性の影響があると寸れば， その現れである触運動に着目寸る必要がでてくる。す なわち，仮想空間で車いすによる移動状況を体験する 場合，自分自身で車いすを漕ぐ際の力覚情報の望示の 必要性がでてくる。そこで, 本章では，標準スケール に扔ける能動性の影響について調べてみる。

$2 \cdot 2$ 実空間における空間認知実験 標準スケー ルにおける能動性の影響を調べるために, 感覚系と連 動系の兼极命いの中で認識が行われるという観点か ら，車いすの移動による空間認知の問題を取り上げ る。すなわち，通常の車いすによる䇛空間での距離の
鼾定奏験を行う。

車いすが淔線移動できる環境を設定し，ゴールに目 標を示古旗を立て，スタート地点からゴール地点の旗 までの移動距離を刺激とする。また，移動方式として， 次の一一考考る。

1. 自己移動方式 (A：active), 被験者自身が車い すを漕ぐ。

2. 補助移動方式( $\mathrm{P}$ : passive), 第三者の人間に 本いすを押してもらう。

被験者は，あらかじめ基準距離 $5 \mathrm{~m}$ を移動して，そ の距離感覚を覚えておき，次に呈示距離を移動する。 本実験では，呈示距離を 4, 6, 8, 10, 12, $14 \mathrm{~m} の 6$ 種 類とする。また， 6 種類の距離をそれぞれ 4 回，ラン ダムに是示する。さらに, 自己移動, 補助移動の雨方 式について実験するため, 被験者一人につき試行回数 は48回となる。

評定距離の国答は，放かじめ覚えてもらった基準 距離との比較で距離を評定し，目盛りづけされた直線 経路の四に，ゴールの位置を書き込む方式で行った。 な抢，目盛りは最小が $50 \mathrm{~cm}$ である。被験者は男性 3 名で，車輪の回転数を数えたりせず，あくまでも直感 的に距離の評定を行うように指示した。

$2 \cdot 3$ 結果と考察実験結果は, 被験者全員の幾 何平均値を用いる。四 1 は，呈示距離に対する評定距 離の幾何平均, 距離ごとの全被験者での最大值, 最小 値を示している。横軸は呈示距離, 縱軸は評定距離で

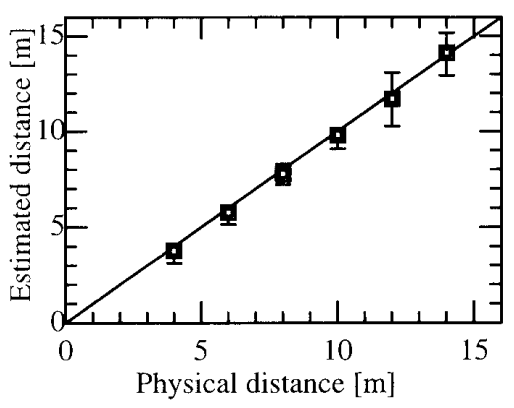

(a) Active movement

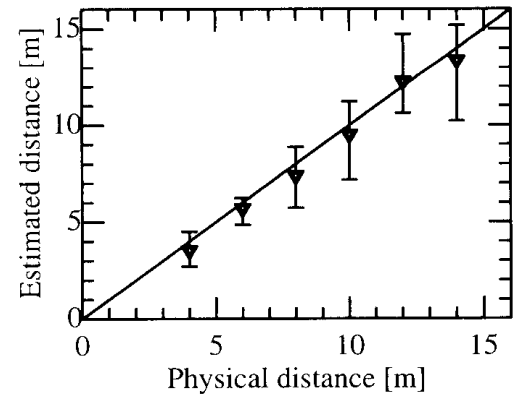

(b) Passive movement

Fig. 1 Results of distance estimate in real environment 
ある。また，図 1(a) は自己移動方式，図 $1(b)$ は補助 移動方式の場合を示している.

図 1 の ( a ) と ( b ) を比較してみると, 明らかに能動 性のある自己移動方式の方が距離の評定のばらつきが 小さい．能動性が欠けている補助移動方式では，呈示 距離が基準距離の $5 \mathrm{~m}$ から長くなるに従って, 評定距 離の值のばらつきが大きくなる。

また，距離ごとの全被験者での評定距離の最大値と 最小値のばらつきを比較してみると, 自己移動方式の 方が, 補助移動方式より小さい。さらに, 評定距離の 詋差について，有意水準 $5 \%$ で $t$ 分布を用いた統計的 検定の結果加ら，自己移動方式と補助移動方式の間に $6 \mathrm{~m}$ の場合を除いて，すべての距離について有意差が 見られた。

以上の結果から，自己移動が能動性の影響を有する ことによって，移動距離の認知の補助をしていると言 える、すなわち, 標準スケールでも視覚一触運動の統 合に対する能動性の影響があると言える。したがっ て，仮想空間で車いすによる移動を体験する場合でも， 車いすを漕ぐ際の力覚情報の呈示が重要であることが わかる。そこで，これまで試作してきた車いす体験シ ステムに力覚呈示機能を付加し, 視覚と力覚を統合し たシステムを製作した。 力覚呈示システムを含めた詳 細を 3 章で述べる。

\section{3. 力覚呈示機能を有する 車いす体験システム}

$3 \cdot 1$ 車いすシステムの全体構成 図 2 に試作し た車いす体験システムの概観図を示す。体験者は，定 位置に固定された車いすに着座, 頭部搭載形デイスプ レイ（HMD）を装着し，車輪のハンドリムを操作す ることで，車いすによる移動を体験できる、車いすの 移動量は，車輪に取付けたロータリエンコーダ（オム ロン製，E6 B 2-CWZ 6 C) から算出し，頭部の動き は，磁気センサ（Polhemus 社製 3 SPACE）により 計測する。

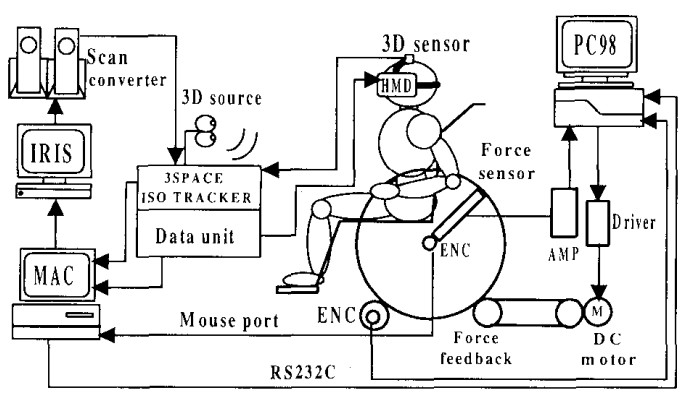

Fig. 2 Experience system of wheelchair
仮想空間内の壁や床などの構造物の映像 (CG) の 構築には，RB 2 システム（VPL 社製）を用いた。車 いすの移動と頭部の動作に応じた仮想空間内の壁や床 などの動画像は，コンピュー夕（Mac）によって計算 し，ワークステーション（IRIS）によって描画する. その画像をスキャンコンバータによって NTSC 信号 (ビデオ信号) に変換し，HMDによって体験者に視 覚呈示する。この視覚星示システムに関しては，前報 (3)，(4)を参照されたい.

\section{$3 \cdot 2$ 力覚呈示システム}

$3 \cdot 2 \cdot 1$ システム構成 図 3 に力覚呈示システム の外観を示す.また，図 4 は力覚呈示システムの構成 図である。図 3 および 4 に示すように，車いすの後輪 は，左右独立に二つのローラの上に乗せられている。 車いすが乗ったローラをDCサーボモータによって， 左右独立に駆動することによって, 力覚呈示機能を車 いす体験システムに付与している，具体的な力覚呈示 方式は，4章で述べることとし，本項では力覚呈示部 のハードウェアについて詳しく示す。

前方のローラには，車いすの移動距離を計測するた めに，ロータリエンコーダ（サンクス製，ORE-38

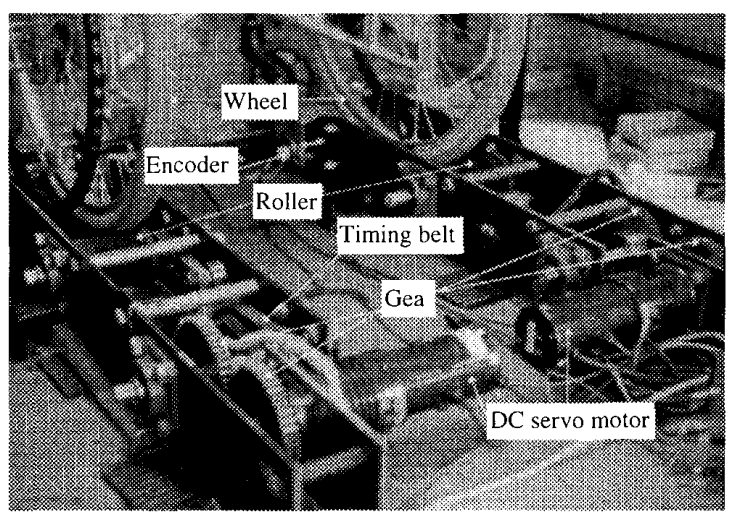

Fig. 3 Force display system

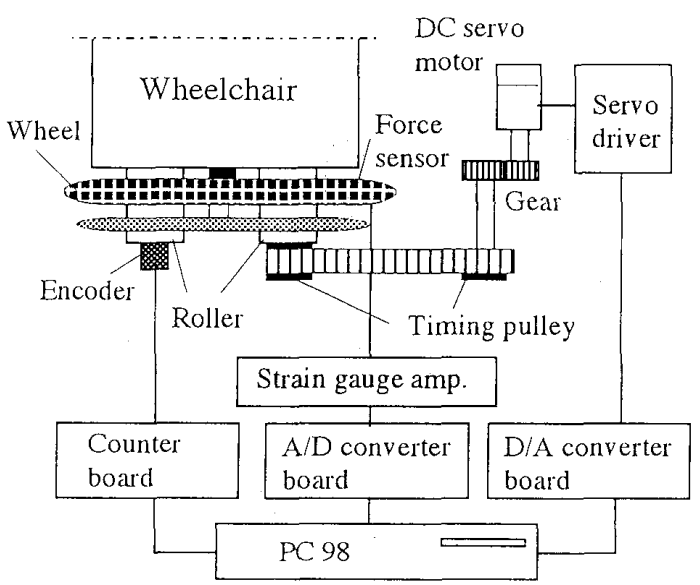

Fig. 4 Force feedback system 
2000 C 05）を取付けた。 エンコーダの分解能は 2000 $\mathrm{P} / \mathrm{R}$ である。また, 制御用のパーソナルコンピュータ （NEC 製，PC 98）に取込むために，エンコーダカウ ンタボード（インタフェース製，AZI-6201）を使用 した.

後方のローラは, DCサーボモータと夕イミングベ ルトおよびプーリを介して結ばれている，力セン机で 体験者が車い寸を漕ぐ力を測定し，力信号をひずみケ ージアンプで増幅した後，A/D 変換器（AZI-3123） を介して制御コンピュー夕に取込む。また，4章で述 べる制御入力を $\mathrm{D} / \mathrm{A}$ 変換器（AZI-3324）を介してサ ーボドライバに出力し， DCサーボモー夕を制御する。

$3 \cdot 2 \cdot 2$ 駆動系 DCサーボモータはハーモニッ クドライブシステムズ製の RHS-20-3007を使用し た。このアクチュエータは, 精密制卸用減速装置(二 ューハーモニックドライブギア) を組込んだ高卜ル ク，高精度のアクチュエータである。本研究で使用し

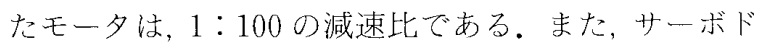
ライバとしてサーボランド製のはん用モーションサー ボ（MOVOSVDM 6-A）を使朋した。

ハーモニックドライブギア付の DCサーボモー夕 は, 図4に示すように1：1のギアを介してタイミン グプーリに接続されている.さらに, タイミングベル トを介してローラに接続され，駆動力が伝達される. またこの駆動系は, 左右に配置されて㧍り, 左有の 車輪に対して，独立に力覚呈示が可能となっている.

$3 \cdot 2 \cdot 3$ 力センサ 体験者の漕ぐ力を測定するた めに，図 5 に示すよjな力センサを自作した。このセ ンサは，センサの一端を車軸側に，もう一端をハンド リム側に取付け，センサのひずみをひずみゲージによ り検出することで, 漕ぐ力を測定している.

構造材としてアルミを使用した。左右のおセンサそ れぞれにつき，4枚のひずみゲージ（共和電気厂業製， KGF-1-120-C 1-23 N 15C2）をはり付けてブリッジ

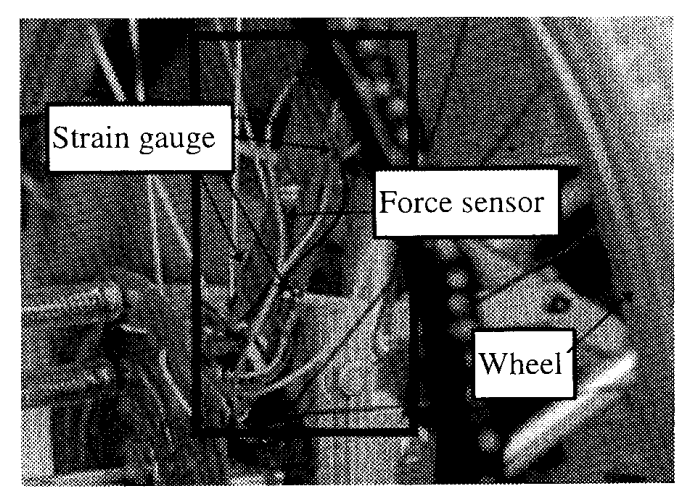

Fig. 5 Force sensor built in wheel
を構成した。またひずみゲージアンプ（ユニパルス 製, AM 20）により信号増幅し, A/D 変換器を介して コンピュータ内に取込む。ささらに，実際の測定結果に 基づいて，最小二乗法による校正を行った。

\section{4. 車いすの運動と力覚呈示}

$4 \cdot 1$ 運動方程式図 6 に, 車いすの運動方程式 を導出する上で必要となるパラメータを前しておく。 $M$ は，体験者が乗った状態での車いすの総重量であ $\eta$

$$
M=M_{1}+M_{2}+2 M_{3}
$$

となる。ここで， $M_{1}$ は体験者の体重， $M_{2}$ は車いす本 体（車輪を除く）の質量, $M_{3}$ は車いすの車輪一つの 質量を表す。また， $g$ は重力加速度であり，後輪にか かる質量比率を入とする。

ここで, 前輪は本体の回転を防ぐために付けたもの で, 転がり摩擦はないものとし, 垂直抗力のみと仮定 する. 平坦路での系全体の運動方程式は, 次のように なる。

$$
M \frac{d v}{d t}=2 \lambda M g \tan \phi
$$

ここで，車いすの速度をvとし，転がり摩擦 $R$ が鉛

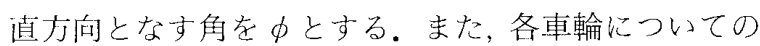
運動方程式は，次のように与えられる。

$$
I \frac{d \omega}{d t}=F r-\lambda M g l-\lambda M g r \tan \phi
$$

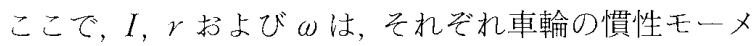
ント，半径および回転速度である。また，Fは体験者 の漕ぐ力であり, $l$ 注転がり摩擦係数である.

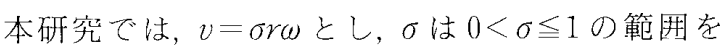
とる滑り係数とする. $I=M_{3} r^{2} / 2$ の関係から, 式( 3 ) は次のように畫き直せる。

$$
\frac{M_{3}}{2} r^{2} \frac{1}{\sigma r} \frac{d v}{d t}=F r-\lambda M g l-\lambda M g r \tan \phi \cdots(4)
$$

式(4)の両辺をとで割り，式(2)を代入し整理する

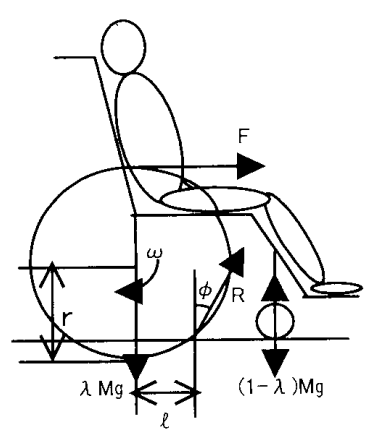

Fig. 6 Systematic definition 
と,

$$
\frac{1}{2}\left(M+\frac{M_{3}}{\sigma}\right) \frac{d v}{d t}=F-\frac{\lambda M g l}{r}
$$

を得る。

一方，坂道の場合では，坂の傾斜角度を $\theta$ とすると (図 7 参照)，系全体の運動方程式は，次のようにな $\eta$,

$M \frac{d v}{d t}=2 \lambda M g \cos \theta \tan \phi-2 \lambda M g \sin \theta \cdots(6)$

平坦路の場合と同様の計算から，

$$
\frac{1}{2}\left(M+\frac{M_{3}}{\sigma}\right) \frac{d v}{d t}=F-\frac{\lambda M g l \cos \theta}{r}-\lambda M g \sin \theta
$$

を得る。

$4 \cdot 2$ 力覚呈示方式 本研究では, 漕ぐ力 $F$ に応 じて車いすの速度（車輪の回転速度）を制御すること によって，力覚を伴った車いすでの移動を再現する。

図 8 に制御系のブロック線図を示す。体験者の漕ぐ 力 $F$ を力七ンサで測定し, 式 (5)あるいは式 (7)の 運動方程式（車いすモデル）功目標速度 $v_{r e f}$ 求 める.この $v_{r e f}$ と実測された車いすの速度 $v$ (車輪 の回転速度から算出された見かけ上の車いすの速度） の偏差 $e$ を比例倍して, サーボドライバに出力する (比例制御)。

以上の制御方式により，力覚呈示機能を実世界と一 致させるための校正実験を行った，実験方法は, 被験 者 2 人に，車いすに乗って，通常の 1 回漕ぎをしても らい, 進んだ距離をそれぞれ 10 回測定し, それらの平 均を取る。次に, 仮想体験システムに抢いて, 同じ動 作と同じ力具合在行ってもらい, 両者の平均移動距離 が一致するように車いすモデルのパラメータ入拉よ びりの調整を行った５章では，この試作したシステ ムに対して, 空間認知に基づく実験的な検証を行う。

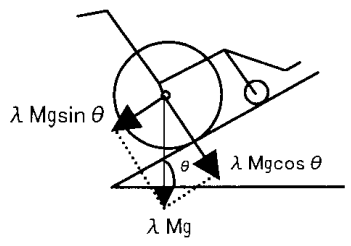

Fig. 7 Hill road case

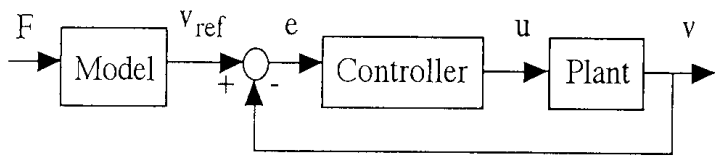

Fig. 8 Block diagram of force feedback control

\section{5. 力覚呈示によるシステムの検証}

$5 ・ 1$ 仮想空間における空間認知実験車いす体 験における力覚呈示の有意性を, 試作したシステムを 用いた空間認知実験, 具体的には移動による距離の評 定実験により検証する。さらに，試作したシステムは， 2 章で述べた実空間での移動状況および空間認知特性 を反映することができるかどうかについて検証する．

実験では，実空間と同椂な環境を仮想空間内に作成 し，スタート地点からゴール地点まで移動することに より得られる距離を刺激とする。本実験では，図 9 に 示すように, 幅 $3 \mathrm{~m}$ の直線経路と高さ $3.2 \mathrm{~m}$ の壁を 準備した。また，被験者には図 9(a)のような映像が 呈示される。

力覚呈示については，次の二つを設定する。

1. 力覚呈示あり (F：with force feedback)

2. 力覚呈示なし ( $\mathrm{N}$ : without force feedback) また，基準距離と評定距離の設定，呈示および回答方 式は，2章での実験と同じとする。

力覚呈示を行わない場合の実験は，単純に図 4 に示 したタイミングベルトを外し，ローラをフリーにした 状態で行う。被験者が車輪のハンドリムをまわすと, それに応じて車輪軸に取付けたロータリエンコーダか ら移動距離が算出され，仮想空間内の映像が提示され る.

$5 \cdot 2$ 実験結果 図 10 に, 仮想空間での被験者全 員の呈示距離に対する回答距離の幾何平均, 距離ごと の最大値, 最小値を示す. 横軸は呈示距離, 縦軸は評 定距離である. 図 10(a) 什力覚呈示がある場合, 図 10 (b) は覚呈示がない場合の結果である。また，実 空間での実験 (2 章) と仮想空間での実験 (本章)，四 つすべてについて, 呈示距離からの平均㕵差，および 標準偏差を求めたものを図 11 に示す。

さらに，実験条件別のデー夕間に有意差が認められ るかを統計的に検討するために，有意水準 $5 \%$ で $t$ 分 布を用いて検定を行った。表 1 は自己移動方式を基準 に, 各評定距離での有意差の有無扔よび誤差の大小関

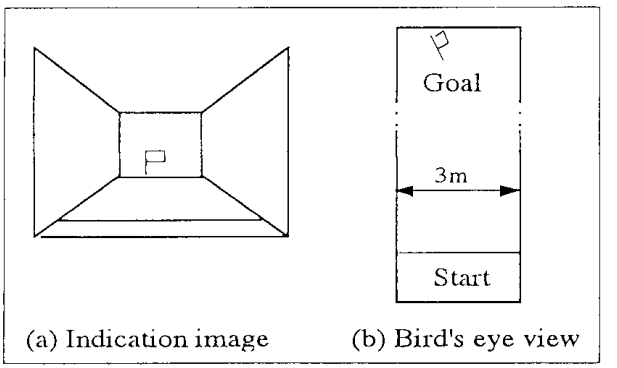

Fig. 9 Virtual environment of experiment 


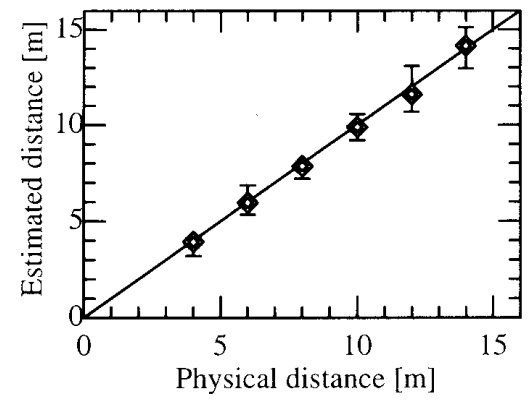

(a) With force feedback

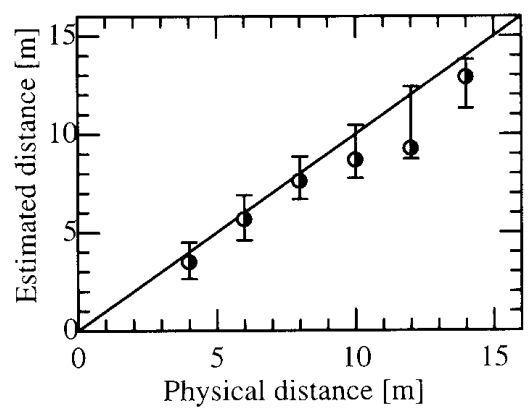

(b) Without force feedback

Fig. 10 Results of distance estimate in virtual environment

係をまとめたものである。ここで, 有意差が見られな い結果は，基準の自己移動方式 (A)と一致していると 認定し, 中央欄に記入した。また，有意差が見られた 結果に関しては, 評定距離の誤差の大小で分けて記入 した. 点差の大は $30 \mathrm{~cm}$ 以上で, 小は $30 \mathrm{~cm}$ 未満と した.

\section{$5 \cdot 3$ 結果の考察と検証}

$5 \cdot 3 \cdot 1$ 力覚呈示の有意性図 10 と 11 の実験紈 果から, 力覚呈示なしと力觉呈示ありを比較してみる と, 評定距離の平均䛊差の絶対值に执いて, 力觉呈示 がある場合のほうが，ない場含より小さくなってい る。また，両者について有意水準 5\%で統計的検定を 行った結果, すべての呈示距離について有意差が見ら れた。さらに, 標準偏差り比 $(\mathrm{Nd} / \mathrm{Fd})$ を計算してみ ると, 表 2 のように, $1.18 \sim 3.13$ となり,力覚呈示な しの場合は，ばらつきが大きいことがわかる。

また，于筧旱示なしの場合核，眓10(b)加らかる ように，過小視傾向が強くでている。一方，自己移動 方式と力覚旺示ありの場合については, 多少, 過小視 しているものの力覚旺示なしの場合ほどではない.

以上の結果から，車いすの移動による空間祬知では， 力覚呈示の有意性があるといえる.

$$
5 \cdot 3 \cdot 2 \text { システムの妥当性四 } 1(\mathrm{a}) \text { と図 } 10(\mathrm{a}) \text {, }
$$

図 11 および表 10 笑験結果から，夹空間での自し移 動方式と仮想空間での力覚是示ありの場合のデータの

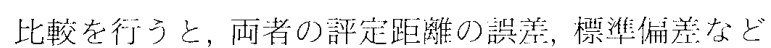

Table 1 Error comparison

\begin{tabular}{|c|c|c|c|}
\hline \multirow[t]{2}{*}{ Distance } & \multicolumn{3}{|c|}{ Error } \\
\hline & Big & Same with basis $(\mathrm{A})$ & Small \\
\hline $4 \mathrm{~m}$ & $P^{*}, N^{*}$ & $\mathrm{~F}$ & \\
\hline $6 \mathrm{~m}$ & & $\mathrm{P}, \mathrm{F}$ & $\mathrm{N}$ * \\
\hline $8 \mathrm{~m}$ & $\mathrm{P}^{*}, \mathrm{~N}^{*}$ & $\mathrm{~F}$ & \\
\hline $10 \mathrm{~m}$ & $\mathrm{P} *, \mathrm{~N}^{*}$ & $\mathrm{~F}$ & \\
\hline $12 \mathrm{~m}$ & $\mathrm{~N}^{*}$ & $\mathrm{~F}$ & $\mathrm{P}^{*}$ \\
\hline $14 \mathrm{~m}$ & $\mathrm{P}^{*}, \mathrm{~N}^{*}$ & $F$ & \\
\hline \multicolumn{2}{|c|}{ A: Active } & \multicolumn{2}{|c|}{ F: With force feedback } \\
\hline \multicolumn{2}{|c|}{ P: Passive } & \multicolumn{2}{|c|}{ N: Without force feedbac } \\
\hline
\end{tabular}
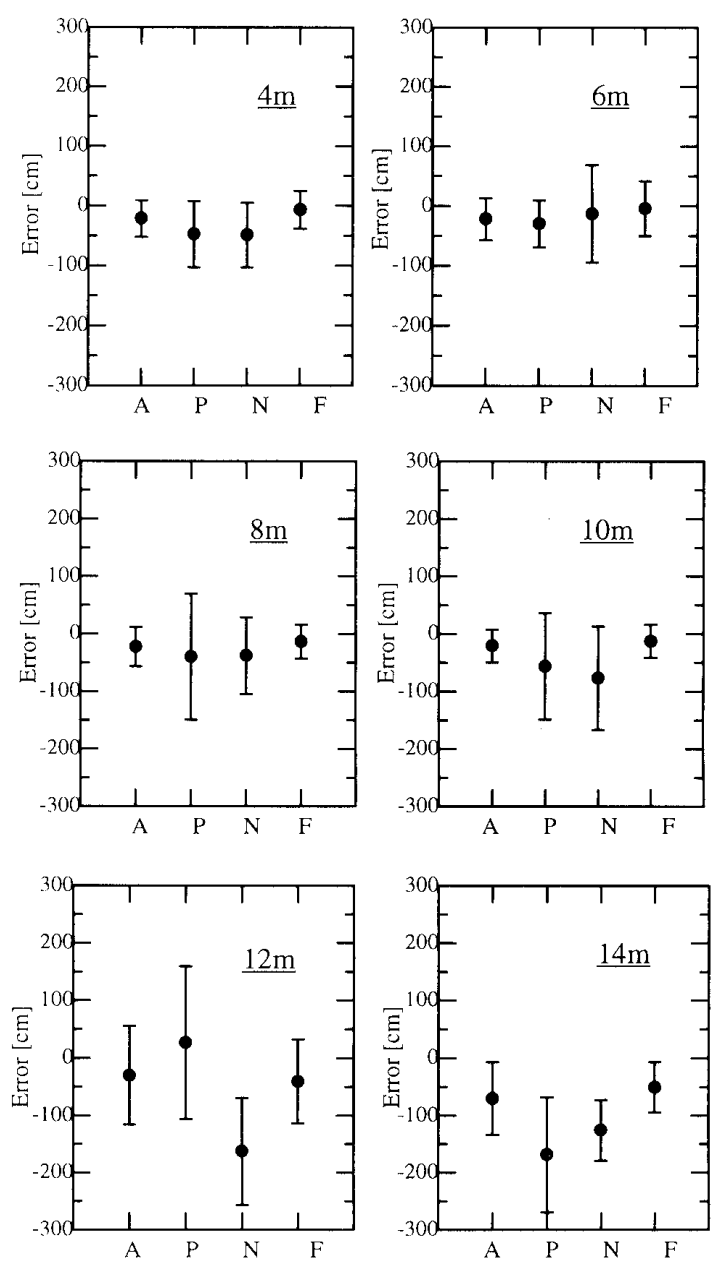
A: Active
$\mathrm{N}$ : Without force feedback
P: Passive
F: With force feedback

Fig. 11 Error and deviation at distance estimate

に関して、ほぼ一致した結果が得られていることがわ かる。

耑者に対して有意水準 $5 \%$ で統計的検定を行った結 果は, 表1に示したように，寸べての呈示距離に対し て，有意差は見ら机なかった。また，表 2 からわかる ように, 標準偏差の比 $(F d / A d)$ は 0.85〜1.30であ り，1に近い值となっている。つまり，実空間と仮想 
Table 2 Results comparison

\begin{tabular}{|c|r|r|r|r|r|r|r|}
\hline \multicolumn{2}{c|}{ Results } & \multicolumn{6}{|c|}{ Distance } \\
\cline { 2 - 8 } \multicolumn{2}{c|}{} & $4 \mathrm{~m}$ & $6 \mathrm{~m}$ & $8 \mathrm{~m}$ & $10 \mathrm{~m}$ & $12 \mathrm{~m}$ & \multicolumn{1}{c|}{$14 \mathrm{~m}$} \\
\hline Error & $\mathrm{Ne}$ & -49.08 & -13.08 & -38.25 & -76.67 & -162.67 & -118.41 \\
$(\mathrm{~cm})$ & $\mathrm{Fe}$ & -6.75 & -4.25 & -13.92 & -12.67 & -40.75 & -48.45 \\
\hline Standard & $\mathrm{Nd}$ & 53.95 & 81.71 & 66.85 & 90.03 & 94.01 & 61.50 \\
deviation & $\mathrm{Fd}$ & 31.71 & 45.85 & 29.42 & 28.69 & 73.17 & 52.12 \\
$(\mathrm{~cm})$ & $\mathrm{Ad}$ & 30.34 & 35.23 & 33.99 & 28.39 & 85.68 & 60.31 \\
\hline $\mathrm{Nd} / \mathrm{Fd}$ & 1.70 & 1.78 & 2.27 & 3.13 & 1.28 & 1.18 \\
\hline $\mathrm{Fd} / \mathrm{Ad}$ & 1.05 & 1.30 & 0.87 & 1.01 & 0.85 & 0.86 \\
\hline
\end{tabular}

Ne: Error in "without force feedback"

Fe: Error in "with force feedback"

Nd: Standard deviation in "without force feedback"

Fd: Standard deviation in "with force feedback"

Ad: Standard deviation in "active"

空間での移動状況扔よび空間認知特性がほぼ一致して いる。これらの結果から，試作した仮想体験システム は，手動車いすによる実際の移動を反映しうるものと いえる.

\section{6. 結 言}

本研究では，福祉分野への人工現実感の応用研究と して車いす体験を取上げた。特に，手動車いすによる 移動状況をよりリアルに体験できるように, 力覚呈示 システムを新たに開発した，力覚呈示の有意性および システムの妥当性を評価・検証するために, 移動によ る空間認知の基礎実験を行った。以下に得られた結果 をまとめる。

（1）実空間での空間認知実験により，移動におけ る視覚一触運動の統合に対して，車いすによる移動と いった標準スケールでも能動性の影響があることが確 かめられ，力覚呈示の必要性に有力な根拠を得た.

（2）力覚呈示システムを新たに開発し，手動車い すの両車輪に，運動を伴う力覚情報の呈示ができるよ
うにし，視覚呈示とともに，仮想体験システムを試作 した。

（3）平坦路と坂道を考虑した車いすの運動方程式 を導出し，速度制御を基礎とした力覚呈示方式を提案 し，実世界と同様な移動状態を実現した。

（4）力覚呈示を行わないと，車いすの移動による 空間認知では，実空間における結果との差，および力 覚呈示がある場合の結果との差が大きくなるため，力 覚呈示の有意性があることがわかった。

（5）実空間と仮想空間での移動状況および空間認 知特性がほぼ一致し，試作した仮想体験システムは， 手動車いすによる実際の移動を反映しうるといえる。 本研究の一部は平成 8 年度科学研究費基盤研究 (B) の助成による。

\section{文献}

（1）舟久保熙康・初山泰弘監修，福祉工学，(1995），2，産業図 書.

（2）藤本英雄編著, 人工現実感の展開，(1994)，37，コ口十社

（3）陳連怡・藤本英雄・原田友康，車い寸体験システムにお ける空間認知の特性, 第 11 回ヒューマン・インタフェ一 ス・シンポジウム論文集，(1995)，483-490.

(4) Chen, L., Fujimoto, H. and Harada, T., Spatial Recognition in 「Wheelchair Experience」 System Using Virtual Reality Technology, Proc. 1996 Jp.-U.S.A. Symp. Flexible Aut om., (1996), 237-240.

（5）福井幸男・法加 2 名，視賞と触賞・办賞の協調動作での 課題, Human Interface $N$ \& R, Vol. 7 (1992), 239-242.

（6）舘暲，人工現実感と運動/行動の制御，計測と制御，33-4 (1994), 316-320.

（7）岩田洋夫・松田敬焉，山凸面を有する仮想空間を歩行す るための人工現実感, 第 6 回七ューマン・インタフェー ス・シンポジウム論文集, (1990-10), 21-24.

（8）赤松幹之・石川正俊, 形状知覚に招ける視-触覚の感覚統 合過程の解析, バイオメカニズム, 10 (1990)，23-32.

（9）箱田裕司編, 認知科学のフロンティア I，(1991)，73，サイ エンス社.

（10）穴吹まほ弓・注か3 名，視触覚統合に扔ける能動性の影 響, Human Interface $N \& R$, Vol. 11 (1996), 273-278. 